\title{
Internal Factors of Academic Entrepreneurship: the Case of Four Malaysian Public Research Universities
}

\section{MoharYusof', Mohammad SaeedSiddiq**, LeilanieMohd Nor ${ }^{* * *}$}

\begin{abstract}
This paper focused on academic entrepreneurship, an emerging phenomenon in Malaysian public research universities. The research demonstrated that academic entrepreneurship produced positive impact on research commercialization and university technology transfer for these public research universities. Academic entrepreneurship was also found to be one of the missing gaps in fulfilling the complete process of research and development up to commercialization. This study provided evidence of the appropriateness of using an organizational framework of academic entrepreneurship to measure the influence of the internal environment in stimulating the level of academic entrepreneurship. The results demonstrated that control systems, organizational culture, human resource management systems and entrepreneurial leadership behaviour were key predictors of academic entrepreneurship in these universities.

Keywords: Entrepreneurship, Corporate Entrepreneurship, Academic Entrepreneurship, Internal Environment, University Technology Transfer, Public Research Universities
\end{abstract}

\section{Introduction}

Academic entrepreneurship is an emerging phenomenon of interest in Malaysian public research universities. It is important because the development of academic entrepreneurship should have a positive impact on research commercialization and university technology transfer for these public research universities. Further, academic entrepreneurship is one of the missing gaps in fulfilling the complete process of research and development up to commercialization. In this study, academic entrepreneurship is articulated as the process of creating economic value through acts of organizational creation, renewal, or innovation that occurs within or outside the

Assistant Professor and Program Director, Bank Rakyat School of Business and Entrepreneurship, UniversitiTun Abdul Razak, Malaysia, email: mohar@unirazak.edu.my.

**Visiting Professor, Graduate School of Business, UniversitiTun Abdul Razak, Malaysia, email: saeedbinsiddiq@unirazak.edu.my.

*** Lecturer, Bank Rakyat School of Business and Entrepreneurship, UniversitiTun Abdul Razak, Malaysia, email: leilanie@ unirazak.edu.my. 
university that results in research commercialization and technology transfer (Yusof et. al., 2009; 2010).

Academic entrepreneurship is a process that occurred within the organizational boundary of the university and it facilitated and encouraged university technology transfer between the university and the industry. Consequently, a higher degree of academic entrepreneurship orientation will result in a greater number of technology transfer activities between the university and the industry. This research was pursued with the view that universities which integrate teaching and research with innovation and entrepreneurialism unleash and provide a vast resource that can be used for the betterment of the supporting and surrounding communities and industries.

With a focus on organizational context and the internal environment, this study examined the internal factors of academic entrepreneurship in Universiti Malaya (UM), Universiti Sains Malaysia (USM), Universiti Kebangsaan Malaysia (UKM) and Universiti Putra Malaysia (UPM) by adopting the corporate entrepreneurship lens and measured academic entrepreneurship as an organization-level construct. An organizational framework was constructed on the theory that internal factors which comprise of control systems, structure, human resource management systems, culture and entrepreneurial leadership behavior influence academic entrepreneurship in a university setting. More specifically, the research aimed to:

- investigate the nature of relationship between the internal factors and the level of academic entrepreneurship in the four public research universities, and,

- propose an organizational model of academic entrepreneurship.

\section{Literature review}

The literature review for this research was done extensively, encompassing an exploration of the field of entrepreneurship, organizational entrepreneurship and academic entrepreneurship. Most importantly, the review and examination of literature was directed towards describing the internal factors that may influence academic entrepreneurship in a university setting; and identifying the dimensions and elements of academic entrepreneurship. In the literature, other than individual entrepreneurs, researchers had posed concepts of teams and organizations as entrepreneurs. There were also efforts to relate entrepreneurship to values and value added concepts.

Entrepreneurship research began to focus on different units of analysis, ranging from individuals and teams to organizations and communities. Entrepreneurship research varied in context examined, such as new firms and organizations, existing corporations, family businesses, franchises and new international entrepreneurial activity. Due to this development, there was concern about how entrepreneurs act and the managerial behavior of the entrepreneur (Bygrave \& Hofer, 1991; Stevenson \& Jarillo, 1990; Meyer et. al., 2002; Shane \& Venkataraman, 2000; Busenitz et. al., 2003; Schildt et. al., 2006; Gregoire et. al., 2006; Morris et. al., 2008). 
The consideration of how entrepreneurs act gave entrepreneurship a practical point of view and led towards the application of entrepreneurship to organizations. This also led to the extension of the corporate entrepreneurship view from merely the study of internal venturing to the study of the ability of organizations to act entrepreneurially (Stevenson \& Jarillo, 1990). Corporate entrepreneurship has become a distinct theme in entrepreneurship research and one of the most cited, densely populated and coherent groups of prior studies. It is also one of the streams in entrepreneurship research which has obtained conceptual convergence. These findings were supported by studies published in Entrepreneurship Theory and Practice in May 2006 issue which conducted bibliometric analyses on entrepreneurshiprelated literature (Schildtet. al., 2006; Gregoireet. al., 2006). In this regard, corporate entrepreneurship was deemed apt to be the background theory for this study.

This study was built on previous and emerging corporate-based literature within the overall discipline of entrepreneurship to explain the nature of academic entrepreneurship. The corporate entrepreneurship perspective was preferred because it offers an alternative to the traditional perspective of entrepreneurship that is centered on the role of the individual and the sequential stages of organizational development as posited by organizational life cycle theory. Further, the perspective has the potential for better understanding the organizational context, institutional setting and the dynamic nature of the academic entrepreneurship phenomenon (Brennan et. al., 2005; Brennan and McGowan, 2006; Llano, 2006, Wood, 2011, Clarysse et. al., 2011).

In addition, the study identified three research categories of university-level entrepreneurship namely 'entrepreneurial university', 'academic entrepreneurship' and 'university technology transfer' in the literature. At times, these concepts have been used interchangeably (O'Shea et. al., 2004, Powers and McDougall, 2005). Previous research and studies on entrepreneurial university, academic entrepreneurship and university technology transfer had been concerned and focused on institutional policies, the organizational and institutional environment, the individual academic entrepreneur and the relationship between the university and its external environment. The research contributed to the literature by delineating the boundaries of university-level entrepreneurship and developed a framework to depict the relationship between the research categories as shown in Figure 1 (Yusof and Jain, 2010).

Synthesizing and evaluating the literature, the research articulated the relationship between the entrepreneurial university, academic entrepreneurship and university technology transfer as follows:

- An entrepreneurial university is a university that strategically adapts the entrepreneurial mindset throughout the organization and extensively practices academic entrepreneurship which is extended beyond the boundary of the entrepreneurial university through university-industry technology transfer activities. 
- Academic entrepreneurship is a process that begins within the organizational boundary of the university. This suggests that an entrepreneurial university can be compared to a less entrepreneurial one by measuring the level of its academic entrepreneurship.

- Academic entrepreneurship facilitates and fosters university technology transfer between the entrepreneurial university and the industry. Thus, a higher degree of academic entrepreneurship orientation will result in a greater number of technology transfer activities between the university and the industry.

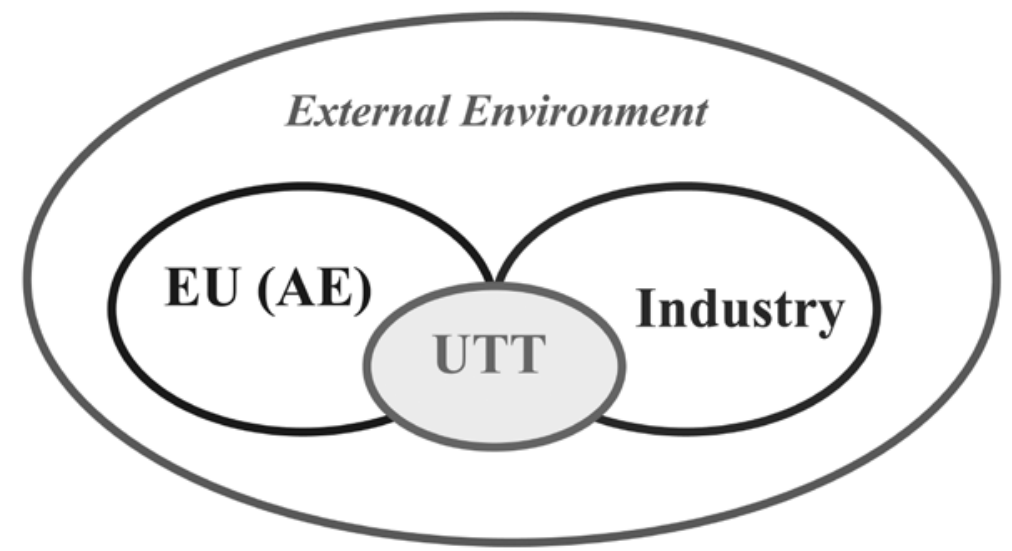

Figure 1. A Framework Depicting the Relationship between University-Level Entrepreneurship, Industry and External Environment

EU - Entrepreneurial University

$\mathrm{AE}$ - Academic Entrepreneurship

UTT - University Technology Transfer

Source: This study and published in Yusof, M. and Jain, K.K. (2010) Categories of University-Level Entrepreneurship: A Literature Survey, The International Entrepreneurship and Management Journal, $6(1), 81-96$.

Several gaps were identified in the literature which included the paucity of research on the influence of internal factors on academic entrepreneurship in university organizations, the unavailability of a uniformed scale to measure academic entrepreneurship at the organizational level of the university, the paucity of research using corporate entrepreneurship as the theoretical lens, the lack of empirical research to explain the phenomenon in the context of Malaysian public research universities, a gap in the understanding of entrepreneurial leadership in the context of research universities and its relationship with academic entrepreneurship and the paucity of research that considered the elements of the internal environment comprising of structure, control systems, human resource management systems and culture in a single study. 
Building upon Ireland et. al.'s (2006a; 2006b) Corporate Entrepreneurship Climate Instrument $\mathrm{CECl}$ model, which theorized that corporate entrepreneurship is stimulated and supported by factors within the internal environment of the organization, the organizational framework of academic entrepreneurship depicted in Figure 2 was developed as the research framework for this study and proposed that the level of academic entrepreneurship, as the dependent variable and measured as an organization-level construct, would be strongly influenced by the identified organizational antecedents. These antecedents became the independent variables of the research framework.

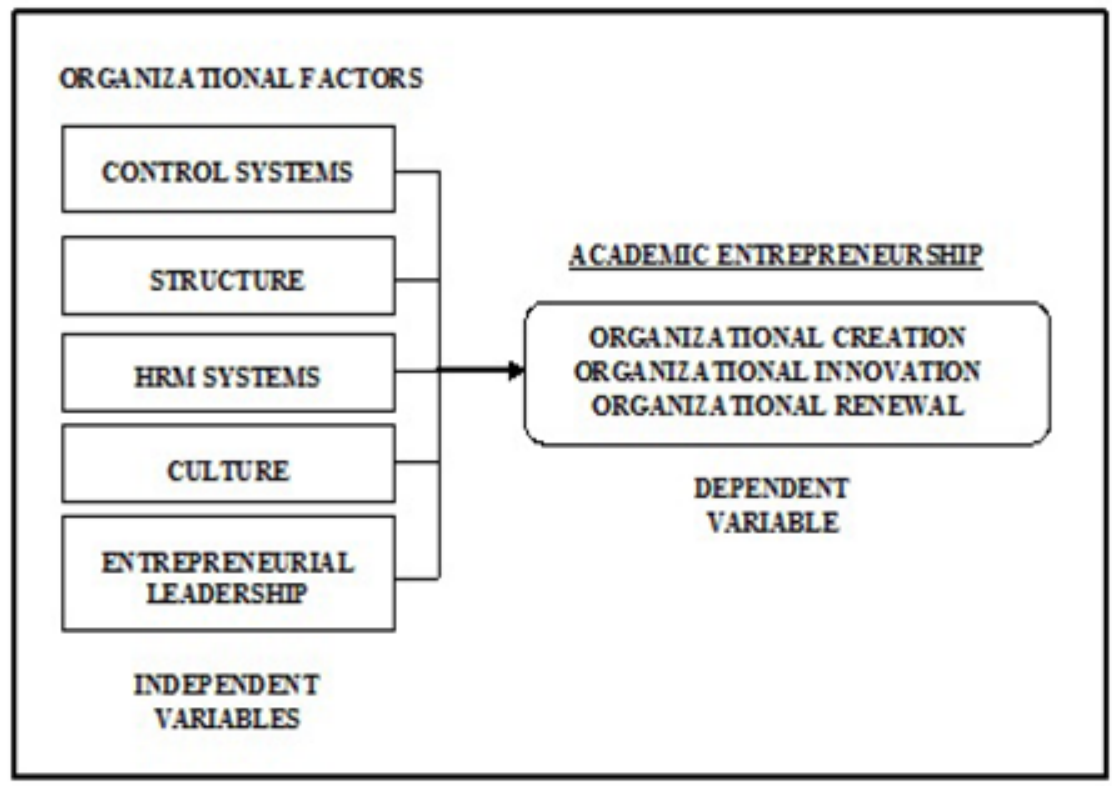

Note: The variable for Inemal Entronment are adopted from In lavd et. al. (2006a. 2006b). The

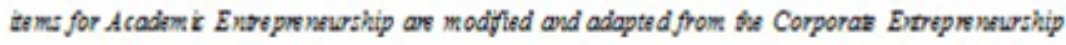
$x$ ale developed by Zalra (1996). Entreprene wrial leaderchip is introduced in this fravenork and its tems are adopted from Thonbern's (2006) General Entreprenewrial Leaderehip zale.

Figure 2. Research Framework

In addition, the research framework proposed that developing academic entrepreneurship in an existing university which has been governed in a bureaucratic manner into an administrative system that facilitates entrepreneurship would require entrepreneurial leadership among academic leaders with skills capable of overcoming various hierarchical and internal constraints, and conflicts. Further, the main challenge in nurturing academic entrepreneurship is to have the ability to build an entrepreneurial mindset which pervades the entire university organization. Thus, the 
study proposed that entrepreneurial leadership behavior should be made an explicit factor in the framework because academic leaders need to create an organizational context that encourages the exhibition of an entrepreneurial mindset and behavior by and among individuals.

The study took the process approach in defining academic entrepreneurship and articulated academic entrepreneurship as organizational processes that results in research and technology commercialization. In this light, research and technology commercialization was regarded as the end outcome of academic entrepreneurship rather than it being academic entrepreneurship itself. Further, these processes involved organizational actions in the form of organizational creation, renewal and innovation. This view broadened the scope of academic entrepreneurship because previous studies tended to equate and limit academic entrepreneurship to just new venture creation.

\section{Research methodology}

The methodology involved the collection and analysis of quantitative data and the implementation of this design were guided by the research framework. This study referred to Brennan et. al.'s (2005) and Brennan and McGowan's (2006) framework that conceptualized the domain of academic entrepreneurship by identifying contributory streams of research, relating these categories to corporate entrepreneurship and used to investigate the enablers and barriers to entrepreneurship taking place in a university setting. This study extended the categorization of academic entrepreneurship based on the dimensions of corporate entrepreneurship by adopting and modifying Zahra's (1996) measure for corporate entrepreneurship.

It was postulated that academic entrepreneurship encompasses internal or external corporate venturing, innovation and strategic renewal performed inside or outside the university. Academic entrepreneurship may occur at the level of individuals or groups of individuals, acting independently or as part of a university system, who create new organizations, or instigate renewal or innovation within the university or outside the university via science and technology parks, university-owned corporate firms or research centers (Chrisman et. al., 1995; Röpke, 1998; Sharma and Chrisman, 1999; Brennan and McGowan, 2006). Table 1 describes the dimensions of academic entrepreneurship. 
Table 1. Dimensions of Academic Entrepreneurship

\begin{tabular}{|c|c|c|}
\hline $\begin{array}{c}\text { Academic } \\
\text { Entrepreneurship }\end{array}$ & Description & Source \\
\hline $\begin{array}{l}\text { Organizational } \\
\text { creation }\end{array}$ & $\begin{array}{l}\text { Venture creation by expanding operations in } \\
\text { existing or new markets through university } \\
\text { start-ups, companies, spin-offs or spin-outs } \\
\text { and strategic alliances, joint ventures or } \\
\text { collaboration with the industry }\end{array}$ & $\begin{array}{l}\text { Chrisman et. al., } 1995 \\
\text { Zahra, } 1996 \\
\text { Sharma \& Chrisman, } 1999 \\
\text { Etzkowitz, } 2003 \\
\text { O'Shea et. al., } 2004 \\
\text { Powers \& McDougall, } 2005 \\
\text { Brennan \& McGowan, } 2006\end{array}$ \\
\hline $\begin{array}{l}\text { Organizational } \\
\text { innovation }\end{array}$ & $\begin{array}{l}\text { The university's commitment to pursue } \\
\text { research and development in creating and } \\
\text { introducing scientific breakthrough, new } \\
\text { inventions and products; introducing new } \\
\text { ways of doing things in terms of production } \\
\text { processes and organizational systems } \\
\text { within the university; and, transferring } \\
\text { and commercializing new knowledge } \\
\text { and technology for economic and social } \\
\text { development }\end{array}$ & $\begin{array}{l}\text { Chrisman et. al., } 1995 \\
\text { Zahra, } 1996 \\
\text { Sharma \& Chrisman, } 1999 \\
\text { Etzkowitz \& Klofsten, } 2005 \\
\text { Röpke, } 1998 \\
\text { Brennan et. al., } 2005 \\
\text { Kirby, } 2006 \\
\text { Morris, Kuratko \& Covin, } 2008\end{array}$ \\
\hline $\begin{array}{l}\text { Organizational } \\
\text { renewal }\end{array}$ & $\begin{array}{l}\text { The transformation of the existing academic } \\
\text { organizations through the renewal or } \\
\text { reshaping of the ideas in which they } \\
\text { are built; by building or acquiring new } \\
\text { capabilities and then creatively leveraging } \\
\text { them to add value for stakeholders; and, } \\
\text { through revitalizing the organization's } \\
\text { operations by changing the scope of its } \\
\text { business, its competitive approach or both }\end{array}$ & $\begin{array}{l}\text { Zahra, } 1996 \\
\text { Sharma \& Chrisman, } 1999 \\
\text { Etzkowitz, } 2003 \\
\text { Meyer et. al., } 2002 \\
\text { Brennan et. al., } 2005 \\
\text { Brennan \& McGowan, } 2006 \\
\text { Kirby, } 2006 \\
\text { Morris, Kuratko \& Covin, } 2008\end{array}$ \\
\hline
\end{tabular}

The internal work environment can profoundly influence the propensity of innovative behavior in academic entrepreneurs. However, this aspect was not given enough attention in past studies on academic entrepreneurship (Brennan and McGowan, 2006). Further, university organizational designs had been identified as key construct of interest in some studies (Etzkowitz, 2003; Etzkowitz and Klofsten, 2005). Organizational or work climate can be defined by an array of elements including the extent of autonomy/control, degree of structure, nature of rewards, consideration, warmth and support (Victor and Cullen, 1988) and there is no single type of work climate (Schneider, 1975).

Ireland et. al.'s corporate entrepreneurship model (2006a; 2006b) identified structure, controls, human resource management systems and culture as crucial when it comes to facilitating or inhibiting entrepreneurship in organizations. This study adopted this particular model to examine the relationship between internal factors and academic entrepreneurship. Table 2 describes the dimensions of the internal environment. 
Table 2. Dimensions of the Internal Environment

\begin{tabular}{|c|c|}
\hline Internal Factors & Description \\
\hline 1. Organizational Structure & $\begin{array}{l}\text { - Horizontal over vertical } \\
\text { - Few layers } \\
\text { - Broader spans of control } \\
\text { - Decentralization } \\
\text { - Cross-functional processes } \\
\text { - Less formalization } \\
\text { - Open communication flow } \\
\text { - Sense of smallness }\end{array}$ \\
\hline 2. Control systems & $\begin{array}{l}\text { - Control based on 'no surprises' } \\
\text { - Loose-tight control properties } \\
\text { - Resource slack } \\
\text { - Internal venture capital pools } \\
\text { - Emphasis on self-control } \\
\text { - Empowerment and discretion } \\
\text { - Mutual trust } \\
\text { - Open information sharing }\end{array}$ \\
\hline 3. Human resource management systems & $\begin{array}{l}\text { - Jobs that are broad in scope } \\
\text { - Multiple career paths } \\
\text { - Extensive job socialization } \\
\text { - Individual and group awards } \\
\text { - High employee involvement in appraisals } \\
\text { - Longer-term reward emphasis } \\
\text { - Appraisal and reward criteria include innovativeness } \\
\text { and risk-taking }\end{array}$ \\
\hline 4. Culture & $\begin{array}{l}\text { - Entrepreneurial learning } \\
\text { - Balanced individual-collective emphasis } \\
\text { - Emphasis on excellence } \\
\text { - Emotional commitment } \\
\text { - Freedom to grow and to fail } \\
\text { - Emphasis on results over process } \\
\text { - Celebration of innovation } \\
\text { - Healthy dissatisfaction and a sense of urgency } \\
\text { - Focus on the future }\end{array}$ \\
\hline
\end{tabular}

Source: Ireland, Kuratko and Morris (2006a; 2006b).

These organizational factors can be barriers to entrepreneurship development in universities due to the inherent nature of education institutions being large organizations and the lack of enterprise tradition within them (Kirby, 2006). It is not the education institutions themselves which are inimical to entrepreneurship but traditional structures, bureaucracy, values and practices. Nevertheless, bureaucratic structures, practices and systems can be molded into a way that enables and arguably stimulates entrepreneurial practices (Sadler, 2001).

This study argued that academic leaders in the university need to behave entrepreneurially in order to stimulate academic entrepreneurship. Hence, it was proposed that the entrepreneurial behavior of academicians enables academic 
entrepreneurship in the university. Entrepreneurial leadership can be described as visionary leadership with inherent focus on opportunities, building/creating, creative destruction/rearrangement, dynamic stake, staged investment, medium term and has an exit strategy (Thornberry, 2006).

There are various leadership theories and instruments that measure leadership behavior. Since the focus of this study was to investigate the level of entrepreneurial behavior in academicians and its association to academic entrepreneurship, Thornberry's (2006) instrument on General Entrepreneurial Leadership behavior was adopted. It was posited that in general, entrepreneurial academic leaders exhibit the following behaviors:-

- Encourage the bending/circumvention of university rules when they get in the way of achieving strategic goals and initiatives,

- Get things done even if it means going around the system,

- Willingly move ahead with a promising new approach when others might hold back,

- Promote an environment where risk-taking is encouraged,

- Encourage others to outwit and outmaneuver the university's bureaucracy,

- Quickly utilize different approaches to overcoming obstacles when the initial one does not work,

- Demonstrate an entrepreneurial orientation at work,

- Actively fight the encroachment of bureaucracy in the university, and,

- Willingly listen to suggestions from others about how to do things differently.

Kuratko and Hornsby (1998) advocated the concept of entrepreneurial leadership as being a critical factor for 21st century organizations. Using corporate entrepreneurship as the focal theory, they espoused the critical relationship an interaction between individuals' behaviors and the organization's internal environment. This relationship and critical interaction are affected by entrepreneurial leadership. Entrepreneurial leaders are supposed to recognize these elements and relationship in enacting entrepreneurship within organizations. These elements include developing the vision of innovation, the development of innovation itself, developing venture teams and structuring an entrepreneurial climate.

\section{Sampling Strategy}

The targeted population frame comprised of academic staff categorized as professors, associate professors, senior lecturers and lecturers. The Directory of Academic Profiles established by the Ministry of Higher Education, Malaysia, was used as the source for the sampling frame. The study obtained statistical, quantitative results from a stratified sample of 312 academicians from the four public research universities. Table 3 demonstrates the distribution of the respondents with respect to their academic designations and divides them into respective universities and stratums. 
Table 3. Sample Distribution by Universities and Stratums

\begin{tabular}{lccccc}
\hline University & Professors & Assoc. Prof. & S. Lecturers & Lecturers & Total \\
\hline UM & 11 & 24 & 21 & 25 & 81 \\
USM & 5 & 15 & 22 & 29 & 71 \\
UKM & 8 & 14 & 24 & 33 & 79 \\
UPM & 16 & 19 & 18 & 28 & 81 \\
Total & 40 & 72 & 85 & 115 & 312 \\
\hline
\end{tabular}

It could be said that senior lecturers were seemingly more willing to answer the survey as compared to the other stratum of respondents. The data collected from the Senior Lecturer stratum far exceeded the desired sample. The key reason for this was because many of the potential respondents identified from the Directory of Academic Profiles (the directory used to sample the population) under the category of Lecturer in 2006-2007 had completed their Ph.D.s and at the time of the survey were already designated as Senior Lecturers. Due to this also, collection of data from the Lecturer category became less successful because the directory was not current and updated at the time of the survey. It was fortunate that data from Professors and Associate Professors were able to be collected and the amount of data collected from these stratums was sufficient for further analysis. Based on the percentage of data collected against the desired size, it could be said that Associate Professors were more willing to answer the survey as compared to Professors. Overall, the final response rate of the survey was $85.9 \%$.

\section{Data Collection Method}

A survey method was chosen to collect data and a common questionnaire was administered to all respondents in the four public research universities. This study utilized a combination of self-administered survey and computer-assisted survey. A self-administered survey is a data collection technique in which the respondent reads the survey questions and records his or her own answers without the presence of a trained interviewer (Hair et. al., 2000; Hair et. al., 2009). The direct mail survey was chosen for this approach. The questionnaire was mailed to a randomly sampled list of people from the Directory of Academic Profiles who answered the questions and returned the completed surveys by mail.

Since the respondents were academicians, it was assumed that they were capable of understanding the questions without the help of interviewers or facilitators; therefore, the direct mail self-administered survey was considered a prudent and suitable method. To produce a high response rate, in addition to mailed surveys, the randomly selected list of people was sent an electronic survey via an electronic-mail where they were encouraged to answer the survey questions linked to a website. Once the respondents completed the survey, they submitted via online and the data was captured in a repository. 
The production of the questionnaire involved designing and pilot testing. The design of the questionnaire involved both the adoption and modification of existing instruments that had been developed by Ireland et. al. (2006b), Thornberry (2006) and Zahra (1996). The questionnaire was divided into two sections namely Section A and Section B. Section A consisted of questions which capture the demographic profile of the respondents. It comprised nine questions which captured the respondents' background such as gender, age, race, working status, academic qualification and academic designation.

Section B consisted of three parts which captured the organizational factors and academic entrepreneurship. Table 4 shows the variables, survey items and related hypotheses.

Table 4. Variables, Survey Items and Related Hypotheses

\begin{tabular}{lll}
\hline \multicolumn{1}{c}{ Variable Name } & \multicolumn{1}{c}{ Survey Items } & Related Hypothesis \\
\hline $\begin{array}{l}\text { Independent variable \#1: } \\
\text { Control systems }\end{array}$ & $\begin{array}{l}\text { Section A, Part I: Questions 1 to 9 } \\
\text { (measure extent of controls) }\end{array}$ & H1 \\
\hline $\begin{array}{l}\text { Independent variable \#2: } \\
\text { Organizational structure }\end{array}$ & $\begin{array}{l}\text { Section A, Part I: Questions 10 to 18 } \\
\text { (measure extent of organizational } \\
\text { structure) }\end{array}$ & H2 \\
\hline $\begin{array}{l}\text { Independent variable \#3: } \\
\text { Human resource } \\
\text { management systems }\end{array}$ & $\begin{array}{l}\text { Section A, Part I: Questions 19 to 27 } \\
\text { (measure extent of human resource } \\
\text { management systems) }\end{array}$ & H3 \\
\hline $\begin{array}{l}\text { Independent variable \#4: } \\
\text { Organizational culture }\end{array}$ & $\begin{array}{l}\text { Section A, Part I: Questions 28 to 36 } \\
\text { (measure extent of culture) }\end{array}$ & H4 \\
\hline $\begin{array}{l}\text { Independent variable \#5: } \\
\text { Entrepreneurial leadership } \\
\text { behavior }\end{array}$ & $\begin{array}{l}\text { Section A, Part II: Questions 1 to 9 } \\
\text { (measure degree of entrepreneurial } \\
\text { leadership behavior) }\end{array}$ & H5 \\
\hline $\begin{array}{l}\text { Dependent variable: } \\
\text { Academic entrepreneurship }\end{array}$ & $\begin{array}{l}\text { Section A, Part III: Questions 1 to 21 } \\
\text { (measure degree of academic } \\
\text { entrepreneurship) }\end{array}$ & H1; H2; H3; H4; H5 \\
\hline
\end{tabular}

Part I, Section B of the questionnaire adopted the items that measure specific organizational variables in Ireland et. al.'s (2006b) Corporate Entrepreneurship Climate Instrument (CECl) which was an adaptation from Hornsby et. al.'s (2002) measurement scale. Part II, Section A of the questionnaire specifically measured entrepreneurial leadership behavior in academic organizations. The items in Section II were adopted from Thornberry's (2006) Entrepreneurial Leadership Questionnaire (ELQ). The Entrepreneurial Leadership Questionnaire maps five dimensions of entrepreneurial leadership. This study adopted the dimension of general entrepreneurial leader behavior only. Further, the scale was modified from a 5-point rating scale that rates importance and frequency to a 5-point Likert scale that measures the degree of entrepreneurial leadership behavior.

Part III, Section A of the questionnaire measures the level of academic entrepreneurship in university organizations. The respondents were asked of their perception on the extent their universities had undertaken such entrepreneurial 
activities over the past three years. Section III mapped three dimensions of academic entrepreneurship which are organizational innovation, organizational creation and organizational renewal. This study modified Zahra's (1996) measure of Corporate Entrepreneurship and revised the items to make it relevant and suitable to the context of university setting.

Section I to III of the questionnaire consisted of items which were described in the form of statements that required the response in the form of Likert scales ranging from 1 to 5 . This was to ensure consistency in using measurement scale. A score of 1 indicates 'Strongly Disagree', a score of 2 means 'Disagree', a score of 3 means 'Neutral', a 4 refers to 'Agree' while a score of 5 indicates 'Strongly Agree'.

A set of the preliminary questionnaire was pilot tested during the period of August 2007 in order to establish that the variables fit into the framework, thereby, establishing validity and reliability. It was first pre-tested and reviewed on the basis of grammar, syntax, spelling, integration and comprehensibility by a professor in the Faculty of Business Administration, Universiti Tun Abdul Razak and a second review was made by a senior lecturer who taught the Research Methodology course at Universiti Malaya.

The questionnaire was distributed at an international conference in Subang Jaya, Selangor and an exhibition which showcased inventions by Malaysian universities held in Kuala Lumpur. Later, it was also emailed to several academicians of two universities in Selangor. In the end, a total of 37 usable responses from academicians and researchers of several universities were collected. Table 5 demonstrates the internal reliability of the scales used in the survey instrument. The results of the reliability analysis for the variables measured through the survey instrument used in the pilot test formed the basis of a revised version which became the final questionnaire.

Table 5. Internal Reliability Score of the Scales Based on the Pilot Test

\begin{tabular}{lc}
\hline \multicolumn{1}{c}{ Variable } & Reliability \\
\hline Control Systems & 0.639 \\
Organizational Structure & 0.472 \\
Human Resource Management Systems & 0.830 \\
Organizational Culture & 0.768 \\
Entrepreneurial Leadership Behavior & 0.861 \\
Academic Entrepreneurship & 0.952 \\
Organizational Creation & 0.910 \\
Organizational Innovation & 0.949 \\
Organizational Renewal & 0.764 \\
\hline
\end{tabular}

\section{Data analysis and key findings}

\section{Demographic Profile of the Respondents}

The demographic profile of the respondents in this study consisted of gender, age, race, working status, highest academic qualification and current academic designation. 
Respondents were asked to provide their background information by answering multiple-choice questions that were designed in the form of nominal scale and recoded into nominal values. A summary of the respondents' demographic characteristics is reported in Table 6.

Table 6. Demographic Characteristics and Frequency Distributions of Sample

\begin{tabular}{|c|c|c|}
\hline Demographic & $\begin{array}{c}\text { Frequency } \\
(\mathrm{N}=312)\end{array}$ & $\begin{array}{c}\text { Valid Percent } \\
\text { (\%) }\end{array}$ \\
\hline \multicolumn{3}{|l|}{ Gender } \\
\hline Male & 173 & 55.4 \\
\hline Female & 139 & 44.6 \\
\hline \multicolumn{3}{|l|}{ Age } \\
\hline 39 or below & 147 & 47.1 \\
\hline 40 to 44 & 69 & 22.1 \\
\hline 45 to 49 & 40 & 12.9 \\
\hline 50 or above & 56 & 17.9 \\
\hline \multicolumn{3}{|l|}{ Race } \\
\hline Malay & 261 & 83.7 \\
\hline Chinese & 28 & 8.9 \\
\hline Indian & 14 & 4.5 \\
\hline Other & 9 & 2.9 \\
\hline \multicolumn{3}{|l|}{ Working Status } \\
\hline Permanent & 264 & 84.6 \\
\hline Contract & 38 & 12.2 \\
\hline Other & 10 & 3.2 \\
\hline \multicolumn{3}{|c|}{ Highest Academic Qualification } \\
\hline $\mathrm{PhD}$ & 204 & 65.4 \\
\hline Master & 101 & 32.4 \\
\hline Other & 7 & 2.2 \\
\hline \multicolumn{3}{|c|}{ Academic Designation } \\
\hline Professor & 40 & 12.8 \\
\hline Associate Professor & 72 & 23.1 \\
\hline Senior Lecturer & 85 & 27.2 \\
\hline Lecturer & 115 & 36.9 \\
\hline
\end{tabular}

\section{Descriptive Analysis of Measurement Scales}

In this section, the descriptive results of the measurement scale for each of the variables of the study are presented. Detailed descriptions of the items or questions, means, standard deviations, skewness and kurtosis are reported in table form. In a quantitative study, to test research hypotheses, normality testing is important, as violation of this assumption could invalidate statistical hypothesis testing. The normality of variables can be tested by skewness and kurtosis (Hair et. al., 2000; Hair et. al., 2009).

With skewness and kurtosis values of less than 1.65 in all of the measurement items for all variables and dimensions, it can be considered that generally, the measurement items were normally distributed and any further treatments of the data, 
such as log-transformation, were not required. The descriptive analysis in the ensuing sub-sections is mainly based on the mean scores of each of the variables and items.

\section{Control Systems}

The scale of control systems consisted of 9 items reflecting the perception of academicians of their university's control on the budget and expense claims for research and development, the level of discretion in undertaking work, efficiency versus effectiveness in resource allocation and whether people talk openly about improving operations. Four of the items (CT1, CT2, СT3 and CT8) were reversecoded. The results of the descriptive analysis for control systems are shown in Table 7. Respondents were asked to provide answers for each item, measured by a five-point Likert scale ranging from ' 1 ' ('strongly disagree') to ' 5 ' ('strongly agree').

From the mean scores, it seems, academicians in these four public research universities agreed that financial support for innovative projects were readily available and accessible $(M=3.91, S D=0.79)$, claims for expenses in doing R\&D did not go through strict control process $(\mathrm{M}=3.72, \mathrm{SD}=1.07)$, budgetary controls were perceived not to be tight $(M=3.59, S D=1.00)$ and authority was allocated to each faculty, school or department $(\mathrm{M}=3.55, \mathrm{SD}=0.87)$. In addition, they fairly agreed that they had a lot of discretion in how they did their jobs $(M=3.44, S D=0.99)$ and felt trusted by the management when it came to using organizational resources $(M=3.47, S D=0.97)$. Further, they were slightly uncertain about the revision that could be done after budgets for $R \& D$ are accepted $(M=3.17, S D=0.99)$ as well as to the effectiveness of these universities in avoiding waste $(M=3.02, S D=0.95)$.

The results of the mean scores for the control systems scale seem to indicate that academicians in these four public universities perceived their organization's control systems to be flexible, convenient and accommodative of their work and responsibilities. The results also demonstrate that academicians felt trusted and were given sufficient discretionary control. In favor of academic entrepreneurship, academicians perceived that there were available and accessible funding for innovative and R\&D projects. Nevertheless, it can be argued also that prudence and more effective control measures need to be put in place to promote innovation and academic entrepreneurship. 
Table 7. Measures of Control Systems

\begin{tabular}{|c|c|c|c|c|c|}
\hline & & & Scale [ & criptions & \\
\hline & $\begin{array}{l}\text { Items } \\
\text { In our university, ... }\end{array}$ & Mean & SD & Skewness & Kurtosis \\
\hline$\overline{\mathrm{CT} 1}$ & ... budgetary controls are tight.* & 3.59 & 1.00 & -0.63 & -0.18 \\
\hline $\mathrm{CT} 2$ & $\begin{array}{l}\text {... claims for expenses in doing R\&D go } \\
\text { through strict control process.* }\end{array}$ & 3.72 & 1.07 & -0.83 & 0.03 \\
\hline CT3 & $\begin{array}{l}\text {... once budgets for R\&D are accepted, they } \\
\text { are difficult to revise.* }\end{array}$ & 3.17 & 0.99 & 0.12 & -0.93 \\
\hline CT4 & $\begin{array}{l}\text {... academicians have a lot of discretion in } \\
\text { how they do their jobs. } \\
\text {... academicians feel trusted by the }\end{array}$ & 3.44 & 0.99 & -0.54 & -0.24 \\
\hline CT5 & $\begin{array}{l}\text { management when it comes to using } \\
\text { organizational resources. }\end{array}$ & 3.47 & 0.97 & -0.63 & -0.27 \\
\hline СТ6 & $\begin{array}{l}\text {... the lines of command clearly allocate } \\
\text { authority to each faculty/school or } \\
\text { department. }\end{array}$ & 3.55 & 0.87 & -0.92 & 0.39 \\
\hline CT7 & $\begin{array}{l}\text {... there are several options for individuals } \\
\text { to get financial support for innovative } \\
\text { projects. }\end{array}$ & 3.91 & 0.79 & -0.95 & 1.39 \\
\hline СТ8 & $\begin{array}{l}\text {... we are effective in avoiding waste.* } \\
\ldots \text { the environment encourages people }\end{array}$ & 3.02 & 0.95 & -0.02 & -0.72 \\
\hline СТ9 & $\begin{array}{l}\text { to talk openly with others about ways to } \\
\text { improve operations. }\end{array}$ & 3.18 & 1.02 & -0.32 & -0.65 \\
\hline
\end{tabular}

Note: Responses to all items were on Likert scale ranging from Strongly Disagree (1) to Strongly Agree (5); *Item was reverse-coded.

\section{Organizational Structure}

Table 8 shows the results of the descriptive statistics of organizational structure. A total of 9 items were measured by a five-point Likert scale on agreement levels, similar to control systems. 5 of the items (ST2, ST4, ST6, ST7 and ST9) were reverse-coded. This measurement scale contains the explanation of the academicians' evaluations of their universities' organizational structures and whether they are flexible thereby facilitating open communication flow, encourages entrepreneurship and experimentation of new ideas.

Based on the results of mean scores, the respondents in this study expressed agreement that there were not many levels of management in their universities $(M=3.96$, $\mathrm{SD}=0.85$ ) and that they were organized in a way that encouraged them to independently manage their research projects $(M=3.71, S D=0.89)$. Further, the academicians perceived that the organizational structure was not clearly defined $(M=3.64, S D=0.82)$, agreed that red-tape was not a problem $(M=3.55, S D=1.04)$ and that administrators believed in delegating decision-making responsibility $(M=3.24, S D=0.9)$.

However, they were uncertain of the flexibility of the organizational structure $(M=3.02, S D=0.93)$. The responses also indicated that the universities' bureaucratic structure did not take away or hinder the ability to be entrepreneurial $(M=3.45$, 
$S D=1.02)$ and did not limit the ability to experiment with new ideas ( $M=3.22, S D=1.01$ ). Overall, the responses demonstrate that even though the organizational structure may not be truly accommodative of entrepreneurship within the universities, it has not hindered or impeded the ability of these universities to be entrepreneurial and innovative.

Table 8. Measures of Organizational Structure

\begin{tabular}{|c|c|c|c|c|c|}
\hline & & & Scale & escriptions & \\
\hline & Items & Mean & SD & Skewness & Kurtosis \\
\hline & In our university, ... & & & & \\
\hline ST1 & $\begin{array}{l}\text {... the organizational structure facilitates } \\
\text { open communication flow. }\end{array}$ & 3.28 & 0.97 & -0.47 & -0.42 \\
\hline ST2 & $\begin{array}{l}\text {... the bureaucratic structure takes away our } \\
\text { ability to be entrepreneurial.* }\end{array}$ & 3.45 & 1.02 & -0.22 & -0.67 \\
\hline ST3 & $\begin{array}{l}\text {... we are organized in a way that encourages } \\
\text { us to independently manage our research } \\
\text { projects. }\end{array}$ & 3.71 & 0.89 & -0.90 & 0.87 \\
\hline ST4 & ... there are many levels of management.* & 3.96 & 0.85 & -1.11 & 1.65 \\
\hline ST5 & ... the organizational structure is flexible. & 3.02 & 0.93 & -0.31 & -0.37 \\
\hline ST6 & $\begin{array}{l}\text {... a rigid chain of command limits our ability } \\
\text { to experiment with new ideas.* }\end{array}$ & 3.22 & 1.01 & -0.16 & -0.73 \\
\hline ST7 & ... red-tape is a problem.* & 3.55 & 1.04 & -0.22 & -0.94 \\
\hline ST8 & $\begin{array}{l}\text {... administrators believe in delegating } \\
\text { decision-making responsibility. }\end{array}$ & 3.24 & 0.90 & -0.55 & -0.23 \\
\hline ST9 & $\begin{array}{l}\text {... the organizational structure is clearly } \\
\text { defined.* }\end{array}$ & 3.64 & 0.82 & -1.11 & 1.53 \\
\hline
\end{tabular}

Note: Responses to all items were on Likert scale ranging from Strongly Disagree (1) to Strongly Agree (5); * Item was reverse-coded.

\section{Human Resource Management Systems}

The human resource management systems scale was measured by 9 items that relate to issues such as incentives for innovation, reward for taking calculated risks, job definition, pursuance of multiple career paths, development of creative potential, evaluation of innovativeness in performance appraisal, concern with process versus performance, balance between individual incentives and team incentives and job promotion based on innovativeness. Similar to the two preceding scales, respondents of this study were asked to indicate their level of agreement, ranging from 1 to 5 on the prescribed issues. Prior to analysis, item HR7 was reverse-coded.

As presented in Table 9, academicians in these four public research universities tended to agree that they could not get ahead if they did not innovate $(M=3.43$, $S D=1.00)$. In addition, they tended to perceive that their creative potential was developed $(M=3.31, S D=1.02)$ and given considerable discretion in how they performed their tasks $(M=3.3, S D=0.85)$. The respondents seemed to agree that in their universities, there was more concern with performance than with process $(M=3.29, S D=0.99)$. Hence, in relation to this, they tended to agree that innovation 
was highly incentivized $(M=3.25, S D=1.04)$ and annual performance appraisals included an evaluation of their innovativeness ( $M=3.2, S D=1.04)$. Interestingly, there seemed to be moderate agreement that academicians could pursue multiple career paths ( $M=3.16, S D=1.03$ ).

However, they felt uncertain on whether their universities rewarded academicians who take calculated risks $(M=3.04, S D=1.01)$ and whether there was balance between incentives for individual initiative and incentives for team collaboration ( $M=3.08$, $S D=0.92$ ). These results imply that the respondents did perceive their universities' human resource management systems to be encouraging innovation. However, risk-taking which is an important element of entrepreneurship was not seen to be adequately encouraged. As entrepreneurship is also built on teamwork, team collaboration needs to be equitably incentivized as well.

Table 9. Measures of Human Resource Management Systems

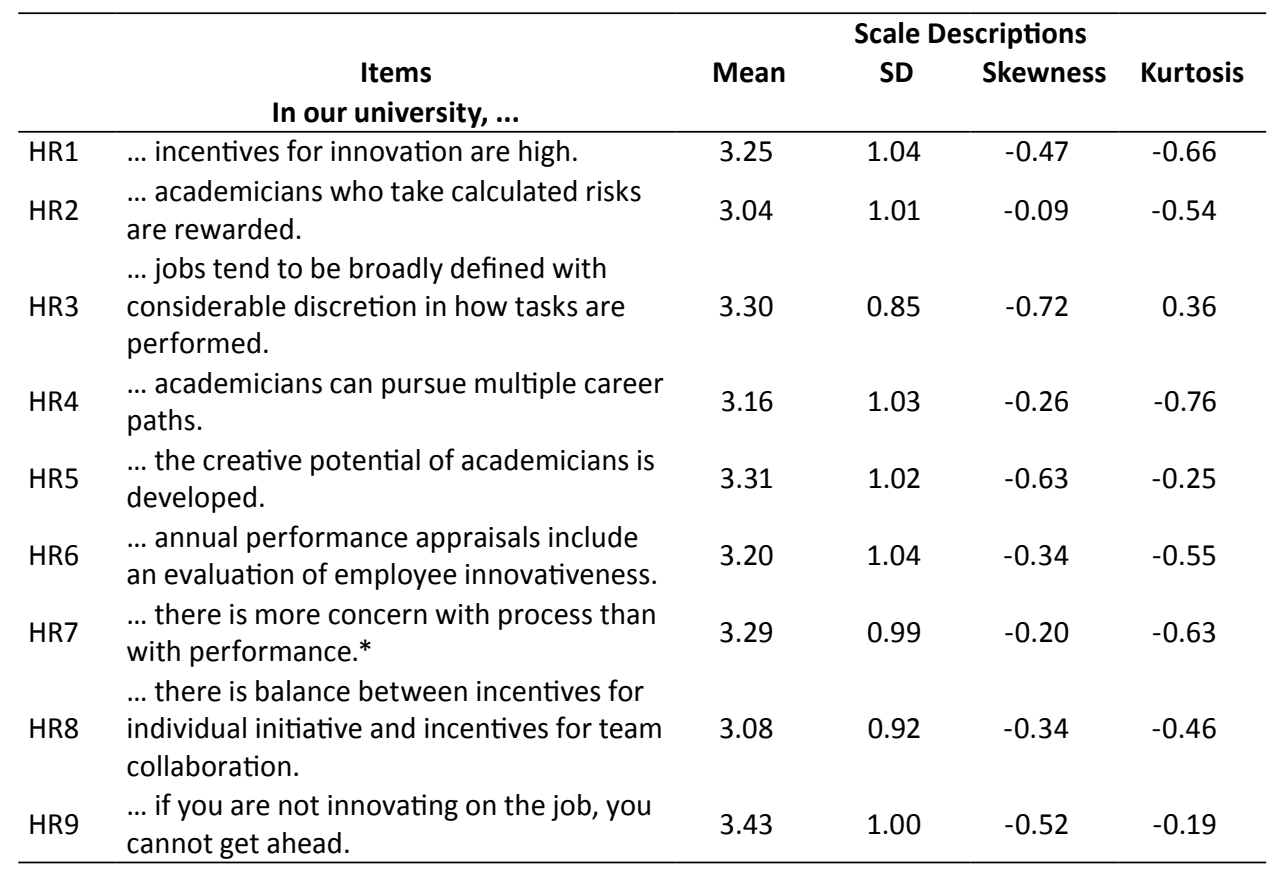

Note: Responses to all items were on Likert scale ranging from Strongly Disagree (1) to Strongly Agree (5); *Item was reverse-coded.

\section{Culture}

The descriptive statistics regarding the universities' culture in promoting innovation and entrepreneurship is reported in Table 10. A total of 9 items was measured by a five-point Likert scale examining agreement with various elements of culture related to idea generation, rewarding tested ideas, celebration of innovative achievements, encouraging failure, a sense of urgency on the importance of innovation, risk-taking 
value, decision making on new ideas and support for experimental projects which may fail. Item CU5 was reverse-coded.

From the results of the means scores, there seemed to be an agreement that these universities celebrated innovative achievements $(M=3.54, S D=1.00)$ and they had a sense of urgency regarding the importance of innovation $(M=3.42, S D=0.98)$. This is in line with the characteristics of research universities. However, the respondents were slightly uncertain about whether their universities' culture encouraged failure $(M=3.27, S D=0.89)$, whether small experimental projects would be supported even though some of them might eventually fail $(M=3.26, S D=0.86)$, whether risk-taking was a core value $(M=3.19, S D=0.9)$ and whether they had a culture that rewarded tested ideas ( $M=3.11, S D=0.92)$.

On the other hand, the respondents seemed to disagree that an employee with a good idea was given free time to develop that idea $(M=2.91, S D=1.02)$ and that employees had a lot of say in how things were done $(M=2.84, S D=0.97)$. These results tend to suggest that even though innovation was encouraged and required among the employees, values, mindsets, behaviors and mechanisms that were needed to support and cultivate entrepreneurship had yet to be inculcated and embodied in the organizations' culture.

Table 10. Measures of Organizational Culture

\begin{tabular}{|c|c|c|c|c|c|}
\hline \multirow{2}{*}{\multicolumn{2}{|c|}{$\begin{array}{l}\text { Items } \\
\text { In our university, ... }\end{array}$}} & \multicolumn{4}{|c|}{ Scale Descriptions } \\
\hline & & Mean & SD & Skewness & Kurtosis \\
\hline CU1 & $\begin{array}{l}\text {... an employee with a good idea is given } \\
\text { free time to develop that idea. }\end{array}$ & 2.91 & 1.02 & -0.10 & -0.81 \\
\hline CU2 & $\begin{array}{l}\text {... employees have a lot of say in how } \\
\text { things are done. }\end{array}$ & 2.84 & 0.97 & 0.03 & -0.85 \\
\hline CU3 & $\begin{array}{l}\text {... ours is a culture that rewards tested } \\
\text { ideas. }\end{array}$ & 3.11 & 0.92 & -0.30 & -0.51 \\
\hline CU4 & ... we celebrate innovative achievements. & 3.54 & 1.00 & -0.48 & -0.50 \\
\hline CU5 & $\begin{array}{l}\text {... we have a culture that discourages } \\
\text { failure.* }\end{array}$ & 3.27 & 0.89 & -0.36 & 0.06 \\
\hline CU6 & $\begin{array}{l}\text {... there is a sense of urgency regarding the } \\
\text { importance of innovation. }\end{array}$ & 3.42 & 0.98 & -0.50 & -0.22 \\
\hline CU7 & ... risk-taking is a core value. & 3.19 & 0.90 & -0.18 & -0.26 \\
\hline CU8 & $\begin{array}{l}\text {...new ideas tend to receive quick go/no go } \\
\text { decisions from the management. } \\
\text {... small experimental projects are }\end{array}$ & 3.07 & 0.82 & -0.07 & -0.50 \\
\hline CU9 & $\begin{array}{l}\text { supported even though some of them may } \\
\text { eventually fail. }\end{array}$ & 3.26 & 0.86 & -0.40 & -0.17 \\
\hline
\end{tabular}

Note: Responses to all items were on Likert scale ranging from Strongly Disagree (1) to Strongly Agree (5); *Item was reverse-coded.

\section{Entrepreneurial Leadership Behavior}


In Table 11, the results of the descriptive analysis of the entrepreneurial leadership behavior variable are presented. A total of 9 items were adopted from Thornberry's (2006) General Entrepreneurial Leadership scale to measure the perception of entrepreneurial leadership behavior among academic leaders at various levels in the four designated public research universities. Respondents were asked to indicate their agreement with each item, measured by a five-point Likert scale.

Low to moderate mean scores seems to indicate that respondents were quite uncertain about the level of entrepreneurial leadership behavior among their universities' academic leaders. Among the items with moderate mean scores include the willingness of academic leaders to move ahead with a promising new approach when others might hold back ( $M=3.3, S D=0.92)$, the willingness of academic leaders to listen to suggestions from others about how to do things differently ( $M=3.27$, $S D=1.05)$, the ability to quickly utilize different approaches to overcome obstacles when the initial approach did not work $(M=3.21, S D=0.93)$ and to get things done even if it meant going around the system $(M=3.17, S D=0.93)$.

In addition, the items with low mean scores seem to be related to two characteristics i.e. work environment and entrepreneurial behavior, and, behavior in confronting bureaucracy. For the former, the respondents were highly uncertain on whether academic leaders promoted an environment that encouraged risk-taking $(M=3.07, S D=0.92)$ and whether academic leaders demonstrated entrepreneurial orientation at work $(M=3.06, S D=0.89)$. For the latter, the results seem to show that respondents were highly uncertain on whether academic leaders encouraged the bending of rules when the rules got in the way of achieving strategic initiatives $(M=3.09, S D=0.88)$, whether academic leaders encouraged others to outwit bureaucracy $(M=2.86, S D=0.95)$ and whether they actively fought encroachment of bureaucracy in the university $(M=2.76, S D=0.89)$. For the last two items, the results also show higher responses of disagreement. These findings would possibly mean that entrepreneurial leadership was not a strong characteristic for academic leaders in Malaysian public research universities. 
Table 11. Measures of Entrepreneurial Leadership Behaviour

\begin{tabular}{|c|c|c|c|c|c|}
\hline \multirow{2}{*}{\multicolumn{2}{|c|}{$\begin{array}{c}\text { Items } \\
\text { In general, academic leaders at various } \\
\text { levels of the university... } \\
\ldots \text { encourage the bending of rules when }\end{array}$}} & \multicolumn{4}{|c|}{ Scale Descriptions } \\
\hline & & Mean & SD & Skewness & Kurtosis \\
\hline LB1 & $\begin{array}{l}\text {... encourage the bending of rules when } \\
\text { they get in the way of achieving strategic } \\
\text { initiatives. }\end{array}$ & 3.09 & 0.88 & -0.17 & -0.38 \\
\hline LB2 & $\begin{array}{l}\ldots \text { get things done even if it means going } \\
\text { around the system. }\end{array}$ & 3.17 & 0.93 & -0.41 & -0.66 \\
\hline LB3 & $\begin{array}{l}\text {... willingly move ahead with a promising } \\
\text { new approach when others might hold } \\
\text { back. }\end{array}$ & 3.30 & 0.92 & -0.47 & -0.35 \\
\hline LB4 & $\begin{array}{l}\text {...promote an environment where risk- } \\
\text { taking is encouraged. }\end{array}$ & 3.07 & 0.92 & -0.13 & -0.58 \\
\hline LB5 & $\begin{array}{l}\text {... encourage others to outwit bureaucracy. } \\
\text {... quickly utilize different approaches to }\end{array}$ & 2.86 & 0.95 & 0.08 & -0.34 \\
\hline LB6 & $\begin{array}{l}\text { overcoming obstacles when the initial one } \\
\text { does not work. }\end{array}$ & 3.21 & 0.93 & -0.41 & -0.53 \\
\hline LB7 & $\begin{array}{l}\text {... demonstrate an entrepreneurial } \\
\text { orientation at work. }\end{array}$ & 3.06 & 0.89 & -0.33 & -0.58 \\
\hline LB8 & $\begin{array}{l}\text {... actively fight the encroachment of } \\
\text { bureaucracy in the university. }\end{array}$ & 2.76 & 0.89 & -0.14 & -0.50 \\
\hline LB9 & $\begin{array}{l}\ldots \text { willingly listen to suggestions from } \\
\text { others about how to do things differently. }\end{array}$ & 3.27 & 1.05 & -0.52 & -0.46 \\
\hline
\end{tabular}

Note: Responses to all items were on Likert scale ranging from Strongly Disagree (1) to Strongly Agree (5)

\section{Organizational Innovation}

Table 12 shows the results of the descriptive statistics for the organizational innovation dimension of academic entrepreneurship. The measurement scale for organizational innovation, adapted from Zahra's (1996) 'Corporate Entrepreneurship' scale, contained seven items. Respondents were asked to indicate their level of agreement based on a five-point Likert scale.

Of all the items, the item with the highest mean score demonstrated that majority of the respondents agreed their universities had spent heavily on R\&D (M=3.81, $S D=0.9)$. In addition, they somewhat agreed that they had increased the amount of knowledge transfers to the industry through $R \& D(M=3.47, S D=0.92)$, had pioneered the development of breakthrough scientific research for local economic developments $(M=3.46, S D=0.93)$, had introduced a large number of new inventions to the market $(\mathrm{M}=3.38, \mathrm{SD}=1.05)$ and their universities had maintained world-class R\&D facilities $(M=3.34, S D=1.03)$. However, despite their agreement to the above 5 items, they seemed to be slightly uncertain about whether they had been successful (compared to other universities) in commercializing inventions $(M=3.26, S D=0.93)$ and whether they had acquired more patents than other universities $(M=3.23, S D=0.97)$. 
Hence, it can be said that most of the efforts relating to innovation at these four public research universities had been focused on research and producing inventions for the industry and local development, however, there was uncertainty or that less effort and emphasis was put on the process of commercializing the research and inventions. It also seems that competition between the universities had been on the amount of research and inventions rather than the extent these research and inventions had been patented or commercialized.

Table 12. Measures of Organizational Innovation

\begin{tabular}{|c|c|c|c|c|c|}
\hline & \multirow[b]{2}{*}{ Items } & \multicolumn{4}{|c|}{ Scale Descriptions } \\
\hline & & Mean & SD & Skewness & Kurtosis \\
\hline & Over the past three years, our university... & & & & \\
\hline El1 & $\begin{array}{l}\text {... has spent heavily (compared to other } \\
\text { universities) on R\&D. }\end{array}$ & 3.81 & 0.90 & -0.90 & 0.97 \\
\hline $\mathrm{E} 12$ & $\begin{array}{l}\text {... has maintained world-class R\&D } \\
\text { facilities. }\end{array}$ & 3.34 & 1.03 & -0.29 & -0.61 \\
\hline EI3 & $\begin{array}{l}\ldots \text { has introduced a large number of new } \\
\text { inventions to the market. }\end{array}$ & 3.38 & 1.05 & -0.38 & -0.44 \\
\hline El4 & $\begin{array}{l}\text {... has acquired more patents than other } \\
\text { universities. }\end{array}$ & 3.23 & 0.97 & -0.05 & -0.13 \\
\hline El5 & $\begin{array}{l}\ldots \text { has pioneered the development of } \\
\text { breakthrough scientific research for local } \\
\text { economic development. }\end{array}$ & 3.46 & 0.93 & -0.55 & 0.18 \\
\hline El6 & $\begin{array}{l}\text {... has been successful (compared to other } \\
\text { universities) in commercializing inventions. }\end{array}$ & 3.26 & 0.93 & -0.40 & 0.20 \\
\hline El7 & $\begin{array}{l}\ldots \text { has increased the amount of knowledge } \\
\text { transfers to the industry through R\&D. }\end{array}$ & 3.47 & 0.92 & -0.55 & 0.09 \\
\hline
\end{tabular}

Note: Responses to all items were on Likert scale ranging from Strongly Disagree (1) to Strongly Agree (5)

\section{Organizational Creation}

Descriptive statistics for the organizational creation dimension of academic entrepreneurship are reported in Table 13. A measurement scale comprised of 7 items adapted from Zahra's (1996) 'Corporate Entrepreneurship' scale was used. Similar to the measurement scale for organizational innovation, respondents were asked to indicate their level of agreement with each item on a five-point Likert scale.

As shown in Table 13, the mean scores of the measurement items were between 3.11 and 3.54. The majority of respondents in this study indicated their moderate agreement with the statement that their universities had received sponsorship from the industry to establish applied research centers to promote new venture creation $(\mathrm{M}=3.54, \mathrm{SD}=0.91)$, had undertaken internal venture development through contract research with the industry $(M=3.53, S D=0.84)$ and had expanded its international operations through strategic alliances $(M=3.41, S D=0.99)$. 
However, the respondents were slightly uncertain on whether their universities were more focused on improving operations as compared to being involved in commercialization activities $(M=3.36, S D=0.83)$. Likewise, they were slightly uncertain to whether their universities had entered new industries through equity involvement in university start-up companies $(M=3.14, S D=0.87)$ and as to whether their universities had established start-up companies through industrial linkages $(M=3.11, S D=0.94)$.

Hence, the results seem to reveal that organizational creation in the form of new venture creation or start-up companies occurs through research centers which were supported by industry sponsorship or industry collaboration via contract research. It also seems to show that academicians in these public universities were less inclined to start or create new ventures or start-up companies on their own. It is also possible that academicians did not feel compelled or encouraged to start their own ventures or start-up companies by their universities.

Table 13. Measures of Organizational Creation

\begin{tabular}{|c|c|c|c|c|c|}
\hline & \multirow{3}{*}{$\begin{array}{l}\text { Items } \\
\text { Over the past three years, our university... }\end{array}$} & \multicolumn{4}{|c|}{ Scale Descriptions } \\
\hline & & Mean & SD & Skewness & Kurtosis \\
\hline & & & & & \\
\hline EC1 & $\begin{array}{l}\text {... has entered new industries through } \\
\text { equity involvement in university startup } \\
\text { companies. }\end{array}$ & 3.14 & 0.87 & -0.12 & 0.11 \\
\hline EC2 & $\begin{array}{l}\text {... has expanded its international } \\
\text { operations through strategic alliances. }\end{array}$ & 3.41 & 0.99 & -0.55 & -0.07 \\
\hline EC3 & $\begin{array}{l}\text {... has undertaken internal venture } \\
\text { development through contract research } \\
\text { with the industry. }\end{array}$ & 3.53 & 0.84 & -0.83 & 0.94 \\
\hline EC4 & $\begin{array}{l}\text {... has received sponsorship from the } \\
\text { industry to establish applied research } \\
\text { centers to promote new venture creation. } \\
\text {... has facilitated the creation of }\end{array}$ & 3.54 & 0.91 & -0.56 & 0.15 \\
\hline EC5 & $\begin{array}{l}\text { entrepreneurial firms from internal } \\
\text { research groups. }\end{array}$ & 3.20 & 0.91 & -0.35 & -0.25 \\
\hline EC6 & $\begin{array}{l}\text {... has established startup companies } \\
\text { through industrial linkages. }\end{array}$ & 3.11 & 0.94 & -0.33 & -0.27 \\
\hline EC7 & $\begin{array}{l}\text {... seems to focus on improving the } \\
\text { performance of its operation, rather } \\
\text { than being involved in commercialization } \\
\text { activities.* }\end{array}$ & 3.36 & 0.83 & -0.52 & 0.68 \\
\hline
\end{tabular}

Note: Responses to all items were on Likert scale ranging from Strongly Disagree (1) to Strongly Agree (5); *Item was reverse-coded.

\section{Organizational Renewal}

Table 14 shows the results of the descriptive analysis for organizational renewal, the third dimension of academic entrepreneurship. The measurement scale for organizational renewal was also adapted from Zahra's (1996) 'Corporate 
Entrepreneurship' scale and it contained seven items. Respondents were asked to indicate their level of agreement based on a five-point Likert scale.

Of all the items, the item with the highest mean score demonstrated that majority of the respondents agreed their universities had initiated several programs to improve the productivity of faculties/schools or departments $(M=3.71, S D=0.82)$. In addition, they somewhat agreed that their universities had reorganized operations to ensure coordination among faculties/schools and departments ( $M=3.46, S D=0.0 .87$ ), seemed to have expanded their mission to include economic enterprising in addition to teaching and research $(M=3.45$, $\mathrm{SD}=0.92$ ), had changed the competitive approach (strategy) for each faculty/school or department $(M=3.44, S D=0.78)$, had established technology transfer schemes to facilitate researchers in commercializing research $(M=3.43, S D=0.91)$ and had established technology transfer offices to market faculties' inventions ( $M=3.39, S D=0.98)$. The respondents somewhat disagreed that their universities had maintained several unprofitable faculties/ schools or departments because of public interests $(M=3.39, S D=0.88)$.

Thus, it can be said that the respondents were aware of the on-going process of transformation for their public research universities but the mean scores somehow also indicate that the process of change had not reached the desired level set by the government and the university's management. Organizational renewal or transformation initiatives may take some time to bear fruits especially in the case of academic entrepreneurship which is an emerging process. Nevertheless, it was good to find, from these results, that these universities had actually geared up on the renewal process.

Table 14. Measures of Organizational Renewal

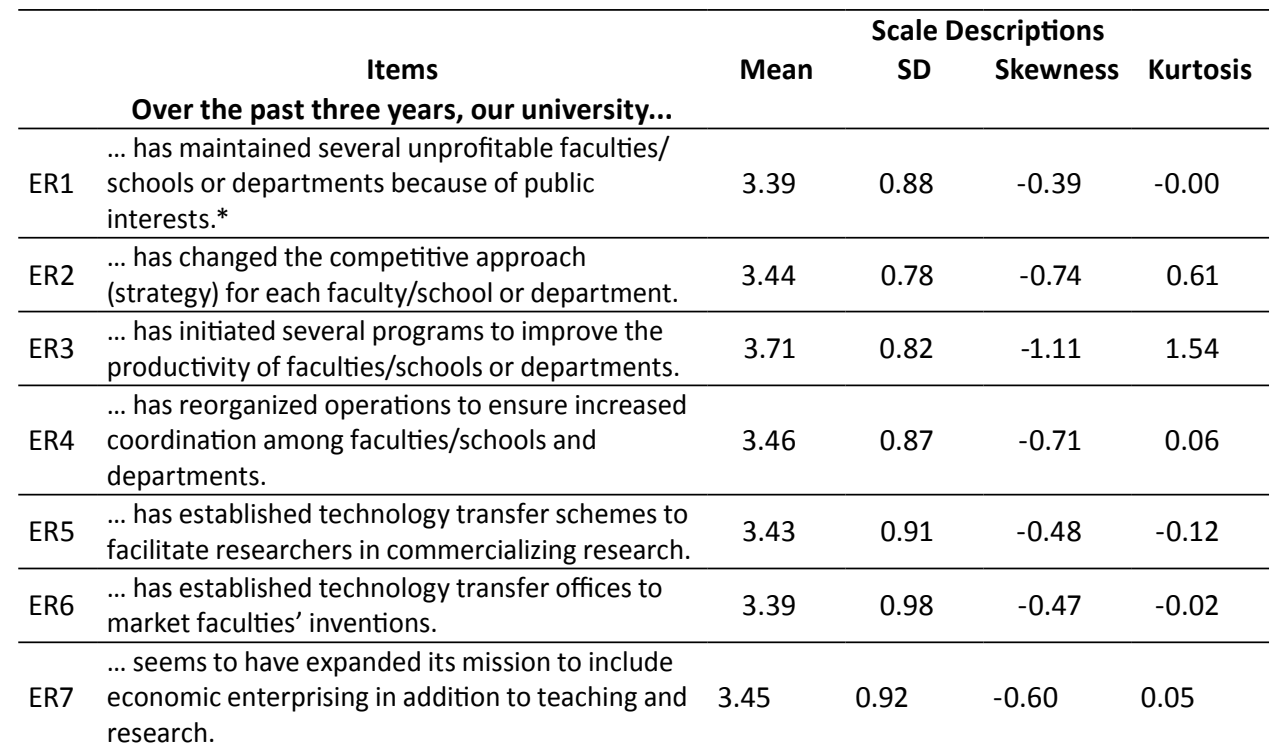

Note: Responses to all items were on Likert scale ranging from Strongly Disagree (1) to Strongly Agree (5); *Item was reverse-coded. 


\section{Reliability Analysis}

Table 15 presents the initial reliability examination of the measurement scales. The Cronbach's alpha coefficients were calculated in SPSS 18. The academic entrepreneurship scale shows the highest alpha value at 0.95 , while the control systems scale indicates the lowest alpha value at 0.68 . Since the Cronbach's alpha values are shown to be 0.68 or above, the variables deployed in this study showed a high degree of internal consistency, thus, meeting the reliability assessment.

In total, 14 items were deleted from the scales of control systems (3 items), organizational structure (4 items), human resource management systems (2 items), culture ( 2 items) and academic entrepreneurship ( 3 items; 1 item from each dimension). The item deletion process was performed in order to increase the alpha value. Items were removed from the scale one at a time when the "Cronbach's Alpha if Item Deleted" column showed that overall reliability could be increased. Upon removing these items and reliability coefficient recalculated, Cronbach alpha values rose to the values shown in Table 15.

Table 15. Reliability Statistics

\begin{tabular}{lc}
\hline \multicolumn{1}{c}{ VARIABLES } & CRONBACH ALPHA \\
\hline CONTROL SYSTEMS & 0.680 \\
STRUCTURE & 0.744 \\
HUMAN RESOURCE MANAGEMENT SYSTEMS & 0.835 \\
CULTURE & 0.810 \\
ENTREPRENEURIAL LEADERSHIP BEHAVIOUR & 0.881 \\
ACAD ACADEMIC ENTREPRENEURSHIP & 0.952 \\
\hline
\end{tabular}

\section{Simple Linear Regression (SLR) Analysis}

The SLR analysis conducted to test five hypotheses found that each independent variable positively and significantly influences the level of academic entrepreneurship in the four public research universities. These findings support findings of previous studies that reiterated on the influence of the internal environment on the level of academic entrepreneurship in academic organizations (Etzkowitz, 2003; Brennan et. al., 2005; Brennan and McGowan, 2006; Llano, 2006; Bercovitz and Feldman, 2008, Clarysse, 2011).

However, the relationship between each organizational factor and academic entrepreneurship was not strong. The Adjusted R Square scores indicated in Table 16 show moderate to strong relationship between human resource management systems and organizational culture with academic entrepreneurship, moderate relationship between control systems with academic entrepreneurship, and, low relationship between organizational structure and entrepreneurial leadership behavior with academic entrepreneurship. 
Table 16. Statement of Hypotheses and Adjusted R Square Scores of Simple Linear Regression Analysis

\begin{tabular}{|c|c|c|c|}
\hline & Hypotheses & Results & Adjusted R Square \\
\hline $\mathrm{H} 1$ & $\begin{array}{l}\text { Control systems which are perceived to support } \\
\text { entrepreneurial activities are positively related } \\
\text { to the level of academic entrepreneurship in the } \\
\text { university }\end{array}$ & Supported $* * *$ & 0.329 \\
\hline $\mathrm{H} 2$ & $\begin{array}{l}\text { An organizational structure which is perceived } \\
\text { to facilitate entrepreneurial development is } \\
\text { positively related to the level of academic } \\
\text { entrepreneurship in the university }\end{array}$ & Supported*** & 0.281 \\
\hline H3 & $\begin{array}{l}\text { Human resource management systems which are } \\
\text { perceived to encourage entrepreneurial behaviors } \\
\text { are positively related to the level of academic } \\
\text { entrepreneurship in the university }\end{array}$ & Supported*** & 0.400 \\
\hline $\mathrm{H} 4$ & $\begin{array}{l}\text { An organizational culture which is perceived to } \\
\text { nurture entrepreneurial behaviors is positively } \\
\text { related to the level of academic entrepreneurship } \\
\text { in the university }\end{array}$ & Supported*** & 0.420 \\
\hline H5 & $\begin{array}{l}\text { The entrepreneurial behavior of academic leaders } \\
\text { in the university significantly influences the level } \\
\text { of academic entrepreneurship in the university }\end{array}$ & Supported*** & 0.295 \\
\hline
\end{tabular}

Note: $* * * p<0.001$

Hence, the results suggest that to increase the level of academic entrepreneurship, these public research universities need to improve and design their control systems, organizational structure, human resource management systems and organizational culture to be able to further stimulate, support, facilitate, nurture and cultivate more entrepreneurial activities among their academicians. In addition, academicians and academic leaders at every level of the university need to behave more entrepreneurially.

\section{Multiple Linear Regression (MLR) Analysis}

MLR analysis was conducted to investigate the association between the identified internal factors and level of academic entrepreneurship in public research universities in Malaysia. Tables 17 and 18 below provide the results of the MLR analysis for five internal factors. Based on the results in Tables 17 and 18, the overall MLR model with the selected five predictors has worked well in explaining the variation in the level of academic entrepreneurship in these public research universities $(F=70.988 ; \mathrm{df}=$ 5,$306 ; p=0.0001$ ).

From Table 18, control systems were found to exert a significant positive influence on academic entrepreneurship ( $t=4.789 ; p=0.0001 ; b=+0.920$ ). Further, human resource management systems was found to exert a significant positive influence on academic entrepreneurship ( $t=4.179 ; p=0.0001 ; b=+0.655)$. In addition, organizational culture was also found to significantly and positively influence academic 
entrepreneurship ( $t=3.610 ; p=0.0001 ; b=+0.629$ ). As for entrepreneurial leadership behavior, it was also found to contribute significantly and positively to academic entrepreneurship ( $t=3.190 ; p=0.002 ; b=+0.339$ ). However, organizational structure was found to be an insignificant predictor of academic entrepreneurship $(t=-0.569 ; p$ $=0.570 ; b=-0.134$ ).

Hence, the estimated regression equation is as follows:-

Academic Entrepreneurship $=6.331+0.92$ Control Systems +0.655 Human Resource Management Systems +0.629 Organizational Culture +0.339 Entrepreneurial Leadership Behavior

Table 17. MLR Results for Internal Factors as Predictors of Academic Entrepreneurship

\begin{tabular}{llrrrrrr}
\hline Model & & $\begin{array}{c}\text { Sum of } \\
\text { Squares }\end{array}$ & df & $\begin{array}{c}\text { Mean } \\
\text { Square }\end{array}$ & F & p & R Square \\
\hline 1 & Regression & 25312.686 & 5 & 5062.537 & 70.988 & 0.0001 & 0.537 \\
& Residual & 21822.382 & 306 & 71.315 & & & \\
& Total & 47135.068 & 311 & & & & \\
\hline
\end{tabular}

a Predictors: (Constant), Control Systems (CT), Human Resource Management Systems (HR), Culture (CU), Organizational Structure (ST), Entrepreneurial Leadership Behavior (LB)

b Dependent Variable: Academic Entrepreneurship

Table 18. Estimated Non-standardized and Standardized Regression Coefficients

\begin{tabular}{lccccc}
\hline $\begin{array}{c}\text { Terms in the } \\
\text { Equation }\end{array}$ & $\begin{array}{c}\text { Non- } \\
\text { standardized } \\
\text { Coefficients } \\
\text { B }\end{array}$ & Std. Error & $\begin{array}{c}\text { Standardized } \\
\text { Coefficients } \\
\text { Beta }\end{array}$ & $\mathbf{t}$ & Sig. \\
\hline (Constant) & 6.331 & 3.143 & & 2.014 & 0.045 \\
CT & 0.920 & 0.192 & 0.260 & 4.789 & 0.000 \\
HR & 0.655 & 0.157 & 0.261 & 4.179 & 0.000 \\
CU & 0.629 & 0.174 & 0.232 & 3.610 & 0.000 \\
ST & -0.134 & 0.235 & -0.035 & -0.569 & 0.570 \\
LB & 0.339 & 0.106 & 0.165 & 3.190 & 0.002 \\
\hline
\end{tabular}

A Dependent Variable: Academic Entrepreneurship

The proportion of explained variance as measured by $\mathrm{R}$ Square for the above regression equation is 0.537 . In other words, 53.7 per cent of the variation in academic entrepreneurship was explained by control systems, human resource management systems, organizational culture and entrepreneurial leadership behavior. The beta values shown in Table 18 seem to indicate human resource management systems as the most important predictor of academic entrepreneurship (Beta $=0.261$ ), secondly is control systems (Beta $=0.260$ ), while organizational culture is the third key predictor (Beta $=0.232$ ). And, the fourth important predictor of academic entrepreneurship is entrepreneurial leadership behavior (Beta $=0.165)$. 


\section{Discussion}

Based on the findings derived from the hypotheses testing, descriptive analyses and regression analyses, the research provided evidence of the appropriateness of using the organizational framework of academic entrepreneurship to measure the influence of the internal environment in stimulating the level of academic entrepreneurship in Malaysian public research universities. As evidenced from previous studies on academic entrepreneurship, organizational factors contribute significantly in enabling and stimulating the level of academic entrepreneurship in academic organisations (Etzkowitz, 2003; Bercovitz and Feldman, 2008; Brennan et. al., 2005; Brennan and McGowan, 2006; Llano, 2006, Clarysse, 2011). The results are in line with the overall findings across several studies in the area of entrepreneurial university, academic entrepreneurship and university-industry technology transfer (Etzkowitz and Klofsten, 2005; Kirby, 2006; Rothaermel et. al., 2007).

The below model in Figure 3 is generated based on the MLR analysis. The analysis found four internal factors i.e. human resource management systems, control systems, organizational culture and entrepreneurial leadership behavior as significant predictors of the level of academic entrepreneurship in public research universities in Malaysia. It was also found that organizational structure as an insignificant predictor of academic entrepreneurship.

The results reinforced organizational culture and human resource management systems as key predictors of academic entrepreneurship. Interestingly, in the context of Malaysian public research universities, control systems emerged as a significant predictor of academic entrepreneurship in the internal environment. In addition, the study included entrepreneurial leadership behaviour as an organizational factor in the research model and proved that it was also a factor that positively and significantly influences the level of academic entrepreneurship.

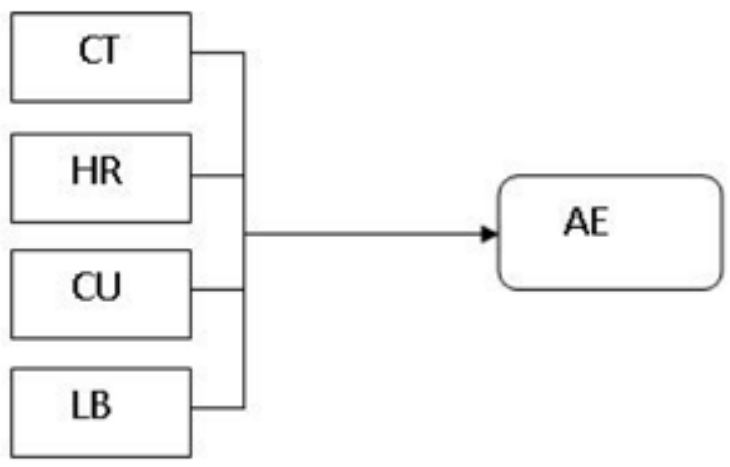

Figure 3. Organisational Model of Academic Entrepreneurship based on the Combined Effects of all Organisational Factors 
There are several limitations to the research. Firstly, the context of the study was the four designated namely UM, USM, UKM and UPM. These universities were designated as research universities in 2006, at the inception of this research. During the Ninth Malaysian Plan 2006-2010 period, USM was accorded the first Accelerated Programme for Excellence (APEX) University in Malaysia. Under the Tenth Malaysian Plan 2011-2015, these four public research universities retained their status as research universities and Universiti Teknologi Malaysia (UTM) was designated as the fifth public research university in Malaysia (EPU, 2006; EPU, 2010). However, UTM was not included in this study because it was only recently that it was designated as a research university by the Malaysian Government.

Secondly, the data for the research was collected from the Directory of Academic Profiles which was established by the Ministry of Higher Education, Malaysia. The directory provided information on academicians comprising their brief personal data, areas of specialization and research contributions. This directory provided a list of potential sampling units that represented an acceptable frame of the defined target population elements which were academicians who would be involved in research activities and academic entrepreneurship. However, there was a possibility that information in the directory had not been continuously updated.

Thirdly, the current investigation was restricted to the context of public research universities; therefore, the generalisation of findings is limited by the characteristics of this specific context. These universities had been long established and were the four biggest universities in Malaysia. Therefore, they were different in terms of size, track record, policy and directions as compared to other universities. It was also viewed that they were more inclined towards academic entrepreneurship as compared to other universities which were deemed to be teaching universities. Thus, generalisations of the findings beyond public research universities such as to public teaching universities, government research institutes and private universities must be cautiously inferred.

Fourthly, the research design for this quantitative study was cross-sectional, whereby all the variables incorporated in the hypothesised model were assessed at a single point in time; hence, no definite conclusions can be drawn concerning the causality of relationships among variables. Therefore, future research via a longitudinal study would provide further significant contributions to knowledge.

\section{Conclusion}

Little has been said on the influence of the internal and organizational context of the university on academic entrepreneurship in the literature. There were some studies on the impact of one or two organizational antecedents on university technology transfer. This study brought the elements of university's internal environment comprising of structure, control systems, human resource management systems, culture and entrepreneurial leadership behavior in a single study. Previous research has either studied a specific relationship between a single organizational antecedent 
and entrepreneurial activity or connected two or more of them together with entrepreneurial activity.

The study provided compelling evidence of the appropriateness of using the organizational framework of academic entrepreneurship to measure the influence of the internal environment in stimulating the level of academic entrepreneurship in Malaysian public research universities. It has contributed in developing a theory and organizational model of academic entrepreneurship. As a result, we know more about what kind of entrepreneurship is likely under various structures, control systems, human resource management systems, organizational culture and entrepreneurial leadership behavior. Further, this study's organisational framework of academic entrepreneurship has extended the study on the integrative view based on corporate entrepreneurship perspective where academic entrepreneurship encompasses organizational creation, innovation and strategic renewal which occurs inside and outside the university.

\section{References}

Bercovitz, J., \& Feldman, M. (2008). Academic entrepreneurs: Organizational change at the individual level. Organization Science, 19(1), 69-89.

Brennan, M.C., Wall, A.P., \& McGowan, P. (2005). Academic entrepreneurship: Assessing preferences in nascent entrepreneurs. Journal of Small Business and Enterprise Development, 12(3), 307-322.

Brennan, M.C., \& McGowan, P. (2006). Academic entrepreneurship: An exploratory case study. International Journal of Entrepreneurial Behaviour and Research, 12(3), 144-164.

Busenitz, L.W., West, III, G.P., Shepherd, D., Nelson, T., Chandler, G.N., \& Zacharakis, A. (2003). Entrepreneurship research in emergence: Past trends and future directions. Journal of Management, 29(3), 285-308.

Bygrave, W.D. (1989). The entrepreneurship paradigm: A philosophical look at its research methodologies. Entrepreneurship Theory and Practice, 14(1), 7-26.

Chrisman, J.J., Hynes, T., \& Fraser, S. (1995). Faculty entrepreneurship and economic development: The case of the University of Calgary. Journal Business Venturing, 10(4), 267-281.

Clarysse, B., Tartari, V., \& Salter, A. (2011). The impact of entrepreneurial capacity, experience and organizational support on academic entrepreneurship. Research Policy, available online 29 June 2011.

EPU 2006. Ninth Malaysian Plan 2006-2010. Putrajaya: The Economic Planning Unit, Prime Minister's Department.

EPU 2010. Tenth Malaysian Plan 2011-2015. Putrajaya: The Economic Planning Unit, Prime Minister's Department.

Etzkowitz, H. (2003). Research groups as 'quasi-firms': The invention of the entrepreneurial university. Research Policy, 32, 109-121.

Etzkowitz, H., \& Klofsten, M. (2005). The innovating region: Toward a theory of knowledge-based regional development. $R$ \& D Management, 35(3), 243-255. 
Gregoire, D.A., Noel, M.X., Dery, R., \& Bechard, J. (2006). Is there conceptual convergence in entrepreneurship research? A co-citation analysis of Frontiers of Entrepreneurship Research, 1981-2004. Entrepreneurship Theory and Practice, 30(3), 333-373.

Hair, J.F., Jr., Bush, R.P., \& Ortinau, D.J. (2000). Marketing research: A practical approach for the new millennium. Boston: Irwin McGraw-Hill.

Hair, J.F., Jr., Bush, R.P., \& Ortinau, D.J. (2009). Marketing research: In a digital information environment. Boston: McGraw-Hill Irwin.

Hornsby, J.S., Kuratko, D.F., \& Zahra, S.A. (2002). Middle managers' perception of the internal environment for corporate entrepreneurship: Assessing a measurement scale, Journal of Business Venturing, 17(3), 253-273.

Ireland, R.D., Kuratko, D.F., \& Morris, M.H. (2006a). A health audit for corporate entrepreneurship: Innovation at all levels, part I. Journal of Business Strategy, 27(1), 10-17.

Ireland, R.D., Kuratko, D.F., \& Morris, M.H. (2006b). A health audit for corporate entrepreneurship: Innovation at all levels, part II. Journal of Business Strategy, 27(2), 21-30.

Kirby, D.A. (2006). Creating entrepreneurial universities in the UK: Applying entrepreneurship theory to practice. Journal of Technology Transfer, 31(5), 599-603.

Kuratko, D.F., \& Hornsby, J.S. (1998). Corporate entrepreneurial leadership for the 21st century. Journal of Leadership and Organizational Studies, 5(2), 27-39.

Llano, J.A. (2006). The university environment and academic entrepreneurship: A behavioral model for measuring environment success. Technology Transfer Society Conference, Georgia Tech, Atlanta, USA, September 27-29.

Meyer, G.D., Neck, H.M., \& Meeks, M.D. (2002). The entrepreneurship-strategic management interface. In M.A. Hitt, R.D. Ireland, S.M. Camp \& D.L. Sexton (Eds), Strategic entrepreneurship: Creating a new mindset (pp. 19-38). Blackwell Publishers Ltd.

Morris, M.H., Kuratko, D.F., \&Covin, J.G. (2008). Corporate entrepreneurship and innovation (2nd edition).Thomson South-Western.

O'Shea, R.P., Allen, T.J., O'Gorman, C., \& Roche, F. (2004). Universities technology transfer: A review of academic entrepreneurship literature. Irish Journal of Management, 25(2), 11-29.

Powers, J.B., \& McDougall, P.P. (2005). Universities start-up formation and technology licensing with firms that go public: A resource-based view of academic entrepreneurship. Journal of Business Venturing, 20(3), 291-311.

Sadler, R. (2001). A framework for the emergence of entrepreneurship and innovation in education, Conference paper for the Centre for the Economics of Education and Training. Retrieved June 20, 2007 from http://www.education.monash.edu.au/ centres/ceet/ docs/conferencepapers/2001confpapersadler.pdf 
Schildt, H.A., Zahra, S.A., \&Silanpaa, A. (2006). Scholarly communities in entrepreneurship research: A co-citation analysis. Entrepreneurship Theory and Practice, 30(3), 399-415.

Schneider, B. (1975). Organizational climate: An essay. Personnel Psychology 28, 447479.

Shane, S., \& Venkataraman, S. (2000). The promise of entrepreneurship as a field of research. Academy of Management Review, 25, 217-226.

Stevenson, H.H., \& Jarillo, J.C. (1990). A paradigm of entrepreneurship: Entrepreneurial management. Strategic Management Journal, 11, 17-27.

Röpke, J. (1998). The entrepreneurial university, innovation, academic knowledge creation and regional development in a globalized economy. Working paper Department of Economics, Philipps-Universität Marburg, Germany, 15. Retrieved February 25 February, 2007 from http://www.wiwi.uni-marburg.de/Lehrstuehle/ VWL/Witheo3/documents/entreuni.pdf.

Rothaermel, F.T., Agung, S.D., \& Jiang, L. (2007). University entrepreneurship: A taxonomy of the literature. Industrial and Corporate Change, 16(4), 691-791.

Sharma, P., \& Chrisman, J.J. (1999). Towards a reconciliation of the definitional issues in the field of corporate entrepreneurship. Entrepreneurship Theory and Practice, 23(3), 11-27.

Thornberry, N. (2006). Lead like an Entrepreneur, New York: McGraw-Hill.

Victor, B., \& Cullen, J.B. (1988). The organizational bases of ethical work climates. Administrative Science Quarterly, 33, 101-125.

Wood, M.S. (2011). A process model of academic entrepreneurship. Business Horizons, 54(2), 153-161.

Yusof, M., Siddiq, M.S., \& Mohd Nor, L. (2009). An integrated model of a university's entrepreneurial ecosystem. Journal of Asia Entrepreneurship and Sustainability, 5(1), 57-77.

Yusof, M., Mohd Nor, L., \& Siddiq, M.S. (2010). Organizational antecedents of academic entrepreneurship in Malaysian public research universities. Asia Pacific Journal of Innovation and Entrepreneurship, 4(3), 43-68.

Yusof, M., \& Jain, K.K. (2010). Categories of university-level entrepreneurship: A literature survey, The International Entrepreneurship and Management Journal, 6 (1), 81-96.

Zahra, S.A. (1996). Governance, ownership and corporate entrepreneurship: The moderating impact of industry technological opportunities. Academy of Management Journal, 39(6), 1713-1735.

\section{Abstract (in Polish)}

Artykuł koncentruje się na przedsiębiorczości akademickiej w publicznych uniwersytetach Malezji. Zgodnie z dotychczasowymi badaniami, przedsiębiorczość akademicka ma pozytywny wpływ na komercjalizację badań i transfer technologii w malezyjskich publicznych uniwersytetach. Wskazuje się ponadto na rolę przedsiębiorczej aktywności jako łącznika między badaniami naukowymi i ich 
rynkowq komercjalizacjq. Na podstawie badań własnych, Autorzy artykułu stwierdzili wpływ wewnętrznych czynników organizacyjnych na poziom rozwoju przedsiębiorczości akademickiej w badanych uniwersytetach. Wykazano, że systemy kontroli, kultura organizacyjna, zarzqdzanie zasobami ludzkimi i przywództwo były kluczowymi predykatorami przedsiębiorczej aktywności w analizowanych uczelniach.

Słowa kluczowe: przedsiębiorczość, intraprzedsiębiorczość, przedsiębiorczość akademicka, środowisko wewnętrzne, uniwersytety publiczne. 